FACULdADE DE CIÊNCIAS ECONÔ MICAS DA UFRGS

MACROECONOMIA DO BRASIL PÓS-1994 LUIZ CARLOS BRESSER-PEREIRA

DESENVOLVIMENTO ECONOMMICO, PREFERÊNCIA PELA LIQUIDEZ E ACESSO BANCÁRIO: UM ESTUDO DE CASO DAS MESORREGIÓES DE MINAS GERAIS

MARCO CROCCO, CLAUDIO BARRA DE CASTRO, ANDERSON CAVALCANTE E VANESSA DA COSTA VAL

FRIEDMAN E O MONETARISMO: A VELHA TEORIA QUANTITATIVA DA MOEDA E A MODERNA ESCOLA MONETARISTA

GENTIL CORAZZAE RODRIGO L. KREMER

BOLLHAS RACIONAIS, CICLO DE PREÇOS DE ATIVOS E RACIONALIDADE LIMITADA: UMA AVALIACAOO CRITICA DOS MODELOS NEOCLÁSSICOS DE BOLHAS ESPECULATIVAS JOSÉ LUIS OREIRO

VULNERABILITY INDICATORS OF THE TWIN CRISES: THE EAST ASIAN EPISODE

TITO BELCHIOR SILVA MOREIRA

IMPACTOS POTENCIAIS DA NEGOCIAÇÃO DA ALCA SOBRE OS INVESTIMENTOS EXTERNOS EM SERVIÇOS PROFISSIONAIS NO BRASIL

MICHEL ALEXANDRE, OTAVIANO CANUTO E GILBERTO TADEU LIMA

TEORIA MARXISTA DO VALOR: UMA INTRODUÇẢO ALFREDO SAAD FILHO

UM ESTUDO EMPIRICO DOS CICLOS POLITICO. ECONOOMICOS NO BRASIL

ATHOS PRATES DA SILVEIRA PREUSSLER E MARCELO SAVINO PORTUGAL

RELENDO CHANDLER, WILLIAMSON E NORTH PARA ENTENDER O PROCESSO DE FORMACĀO DAS ESTRADAS DE FERRO NO BRASIL

JEFFERSON ANDRONIO RAMUNDO STADUTO

WEIMAR FREIRE DA ROCHA IR. E CLAIITON ATAIDES DE FREITAS

MATRIZ DE INSUMO-PRODUTO PARA A ECONOMIA TURISTICA BRASILEIRA: CONSTRUCCÃO E ANÁLISE DAS RELAÇÓES INTERSETORIAIS

FRANCISCO CASIMIRO FILHO E JOAQUIM JOSÉ MARTINS GUILHOTO

SEÇĀO ESPECIAL: AVALIAÇŌES INICIAIS DA POLITTICA ECONÓMICA DO GOVERNO LULA

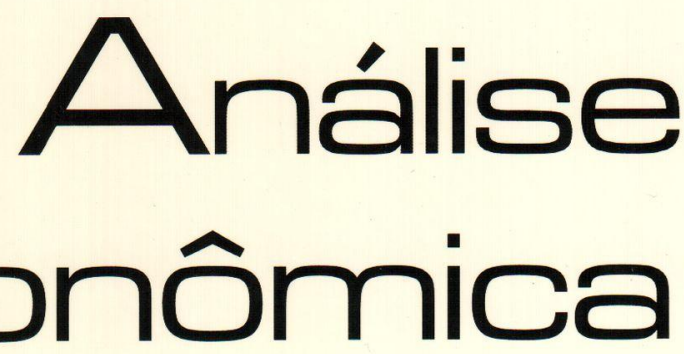


Universidade Federal do Rio Grande do Sul

Reitora: Profa. Wrana Maria Panizzi

Faculdade de Ciencias EConómicas

Diretora: Prof Pedro César Dutra Fonseca

Centro de Estudos e Pesquisas Economicas

Diretor: Prof. Gentil Corazza

Departamento de Ciéncias económicas

Chiefe: Prof. Ricardo Dathein

Curso de Pós. Graduação em Economia

Coordenador: Prof. Eduardo Pontual Ribeiro

Programa de Pós-Graduação em Desenvolvimento Rural

Coordenador: Prof. jalcione Almeida

CONSElHo EDITORIAL:

Carlos G. A. Mielitz Netto (UFRGS), Eduardo A. Maldonado Filho (UFRGS), Eduardo P. Ribeiro (UFRGS), Eleutério F. S. Prado (USP), Eugênio Lagemann (UFRGS), Fernando Cardim de Carvalho (UFRJ), Fernando Ferrari Filho (UFRGS), Fernando de Holanda Barbosa (FGV/RJ), Flávio Vasconcellos Comim (UFRGS), Gentil Corazza (UFRGS), Giácomo Balbinotto Netto (UFRGS), Gustavo Franco (PUC/RJ), Jan A. Kregel (UNCTAD), João Rogério Sanson (UFSC), Joaquim Pinto de Andrade (UnB), Jorge Paulo Araújo (UFRGS), Marcelo S. Portugal (UFRGS), Maria Alice Lahorgue (UFRGS), Paul Davidson (University of Tennessee), Paulo D. Waquil (UFRGS), Pedro C. D. Fonseca (UFRGS), Philip Arestis (Levy Economics Institut of Bard College), Roberto C. de Moraes (UFRGS), Ronald Otto Hillbrecht (UFRGS), Sabino da Silva Porto Jr. (UFRGS), Stefano Florissi (UFRGS) e Werner Baer (University of Illinois at UrbanaChampaign).

COMISSÃO EDITORIAL:

Eduardo Augusto Maldonado Filho, Fernando Ferrari Filho, Gentil Corazza, Marcelo Savino Portugal, Paulo Dabdab Waquil e Roberto Camps Moraes.

EDIroR: Prof. Fernando Ferrari Filho

Editor Adunnio: Prof. Gentil Corazza

SECRETÁrla: Clarissa Roncato Baldim

REVISÁO DE TEXTOS: Vanete Ricacheski

EDITORaÇão Eletrónica: Vanessa Hoffmann de Quadros

Fundador: Prof Antônio Carlos Santos Rosa

Os materiais publicados na revista Análise Econômica são da exclusiva responsabilidade dos autores. É permitida a reprodução total ou parcial dos trabalhos, desde que seja citada a fonte. Aceita-se permuta com revistas congêneres. Aceitam-se, também, livros para divulgação, elaboraçāo de resenhas e recensōes Toda correspondência, material para publicaçāo (vide normas na terceira capa), assinaturas e permutas devem ser dirigidos ao seguinte destinatário:

Análise Econômico

PROF FERNANDO FERRARI FILHO Revisła Análise Econômica - Av. João Pessoa, 52 CEP 90040-000 PORTO ALEGRE - RS, BRASL Telefones: (051) 316-3513 - Fax: (051) 316-3990 E-mail: rae@ufrgs.br

Ano 21, $n^{\circ} 39$, março, 2003 - Porto Alegre

Faculdade de Ciências Econômicas, UFRGS, 2003

Periodicidade semestral, março e setembro.

Tiragem: 500 exemplares

1. Teoria Econômica - Desenvolvimento Regional.

Economia Agrícola - Pesquisa Teórica e Aplicada -

Periódicos. I. Brasil

Faculdade de Ciências Econômicas,

Universidade Federal do Rio Grande do Sul 


\title{
Vulnerability Indicators of the Twin Crises: the East Asian Episode
}

Tito Belchior Silva Moreira**

\begin{abstract}
Resumo: Este artigo propõe um teste empírico com indicadores macroeconômicos, relativo aos setores bancário e externo no período pré-crise em 1996, para identificar grupos de países susceptíveis à crise do leste asiático em 1997-98. Neste contexto, nós estimamos escores de crise para uma amostra de 18 países com base em indicadores dos setores bancário e externo. Aplicamos análise de agrupamento aos escores de crise para estratificar os países em dois grupos homogêneos (mais vulneráveis e menos vulneráveis à crise). Os países mais vulneráveis à crise são Tailândia, Indonésia e Coréia.
\end{abstract}

Palavras-chave: Crises gêmeas e crises do leste asiático JEL Classification: F30, F41

\section{Introduction}

The papers that were then published responded to the demands for explanations about the currency crises with the use of two basic families of models: first-generation models and second-generation models. The first-generation models explain the currency crises based on macroeconomic foundations. The second-generation models show that the deterioration of the macroeconomic foundations is not a necessary condition for the occurrence of speculative attacks. In fact, as those models have multiple equilibriums, they create opportunities for the occurrence of self-fulfilling crises. However, after the Asian currency turmoil, neither of those approaches has been considered satisfactory, despite the fact that many of the East Asia countries that have had currency crises have also had full-fledged domestic banking crises around the same time. The interaction between banking and currency problems has already been discussed

\footnotetext{
- Department of Economics, Catholic University of Brasilia - tito@pos.ucb.br

-. We are grateful to Maurício Barata, Geraldo da S. e Souza, José Roberto Novaes, Maria Luiza Falcão and Geraldo Sant'ana de C. Barros for helpful suggestions.
} 
by Díaz-Alejandro (1985), Velasco (1987), Calvo (1995), Goldfajn and Valdés (1995), Miller (1995) and Moreira (2002).

One of the explanations for the Asian crisis is attributed to the phenomenon called twin crises, which consists of a banking crisis and a crisis in the balance-of-payments, simultaneously. A pioneer empirical work in this area is Kaminsky and Reinhart's (1996, 1999). Following the twin crises approach, Glick and Hutchinson (1999) found evidence that that phenomenon is more common in emerging markets that took up financial liberalization. Those authors have concluded that the opening of the emerging markets to the international flow of capital, plus a structure of financial liberalization, makes those countries particularly vulnerable to the twin crises.

This paper discusses an empirical test with macroeconomic indicators, regarding the banking and external sectors in the precrisis period (1996), to identify countries clusters susceptible to East Asia crisis (1997-98). In this context, we estimate crisis scores for a sample of eighteen countries based on banking and external sectors indicators. The countries with the largest scores reveal more vulnerability to the crisis. We have applied cluster analysis to the crisis scores to stratify the countries into two homogenous groups (most vulnerable and least vulnerable).

The sample is restricted to 18 countries (Argentina, Brazil, Chile, Singapore, Colombia, Korea, the Philippines, Indonesia, Jordan, Malaysia, Mexico, Peru, Poland, the Czech Republic, Sri Lanka, Thailand, Turkey and Venezuela) due to lack of data regarding some of the economic variables of interest in the period. Non-performing loans, for example, wasn't an usual financial indicator until the Asian crises in 1997. The International Monetary Fund and World Bank didn't focus this kind of indicator. Then, in the pre-crises period, (1996), just few countries had this date.

The paper is organized as follows. In Section 2, we present the methodological approach for the construction of the crisis index, the criteria for principal components and cluster analysis, and the validation of the countries classification. In Section 3, we present the twin crises indicators. In Section 4, we show statistical results. Finally, in Section 5, we summarize our findings and present our final comments. 


\section{Methodological approach}

Essentially, our approach for the evaluation of currency crises involves the characterization of a one-dimensional crisis index. We define the indicator of vulnerability of a group of countries to the twin crises, currency and financial crises as

$$
I=\sum_{i=1}^{n} \gamma_{i} \psi_{i} X_{i}
$$

where $n=6, \gamma_{i}$ is the direction (sign) established for $X_{i}$ with base in Principal Components Analysis, and

$$
\psi_{i}=\frac{R_{i}^{2}}{\sum_{j=1}^{n} R_{j}^{2}}
$$

where $\mathrm{Ri}^{2}$ represents the coefficient of determination of the regression of $X_{i}$ in all other variables.

The index $I$ is similar to a general factor in a model of Factor Analysis or Principal Components The weight $\phi_{i}$ is a proxy for the relative communality of the variable $X_{i}$. See Harman (1976), Manly (1994), Wichern and Johnson (1998) and Hoffmann (1999). The index $I$ allows the ranking of the 18 countries in the sample in accordance with the intensity with which they respond to this aggregated measure of vulnerability to the twin crisis.

The availability of the measure I leads naturally to the investigation on the existence of homogenous strata, i.e., conglomerates of countries with similar scores. We make use of the Ward method of classification (Everitt and Dunn, 2001), and of the Euclidean distance in this investigation. Ward's technique is a hierarchical classification method that tries to form clusters with the smallest possible variability within clusters. The classification process is validated by using discriminat analysis (Tabachnick and Fidell, 2001).

The methodological approach intend to identify countries clusters susceptible to East Asia crisis (1997-98) with base in the indicators presented in section 3 using data of 1996. The validity of those indicators must be checked to knowing whether they are good leading indicators on the crisis. At first, we use a principal component analysis to verify if all the indicators are correlated with their respective components and observe the respective signs of them, and finally, interpreting the rotated solution. A advantage this statistical approach 
is that each component can be interpreted as a construct and we can say which one better explain the issue, twin crises. In other words, the $1^{\text {st }}$ Component explain better than the $2^{\text {nd }}$ Component, and the $2^{\text {nd }}$ Component explain better then the 3 th one, and so forth. After that, we measure a crises index based on a weighted average of leading indicators, using the signs extracted by Principal Component Analysis to each indicator respectively. At least, we stratified the countries into two homogenous groups relative to their level of vulnerability using pre-crisis information data and confirm the process using discriminant analysis.

Another important aspect that requires mentioning is the fact that most leading indicators presented in the literature are calculated separately for each country and that they are estimated from time series. We have already mentioned that it is impossible for us use time series, once non-performing loans, for example, wasn't an usual financial indicator until the Asian crises in 1997.

\section{Twin crises indicators}

Also based on the same sample of 18 countries, we investigate the possibility that the currency instability in East Asia resulted from twin crises. The ten variables selected for this analysis are listed below:

i) External sector: $(E)=$ real exchange rate; $(C A / G D P)=$ current account balance relative to GDP; $(\mathrm{M} 2 / \mathrm{R})=$ broad money relative to gross international reserves; $(\mathrm{STFD} / \mathrm{R})=$ short-term foreign debt relative to gross international reserves;

ii) Banking sector: $\left(\mathrm{L}^{*} / \mathrm{GDP}\right)=$ bank gross foreign liabilities relative to GDP; $(\mathrm{C} / \mathrm{GDP})=$ credit to private sector relative to GDP; $(\mathrm{L} / \mathrm{GDP})=$ bank deposits liabilities relative to GDP; $(\mathrm{JV} / \mathrm{Jd})$ = ratio of lending-todeposit interest rate; $(\mathrm{NPL} / \mathrm{TBA})=$ non-performing loans relative to total bank assets; $(\mathrm{M} 2 / \mathrm{R})=$ broad money relative to gross international reserves;

iii) Real sector: $(\mathrm{Y})=$ real GDP growth.

This list is not exhaustive regarding crisis indicators. We realize that many others, like the terms of trade, the M2 multiplier, the stock prices, and so forth, were not considered. However, at least for the East Asia crisis analysis, the indicators listed are satisfactory, once all of them support the external and financial sectors. In fact, if a model is more parsimonious, that's better. Furthermore, we note that it has been commonly used in the literature. See Pill and Pradhan (1995), 
Mishkin (1996), Galbis (1993), Velasco (1987), Kaminsky and Reinhart (1998), Kaminsky and Reinhart (1999), Diehl and Schweickert (1998), Krugman (1998a) and Hardy and Pazarbasioglu (1998).

\section{Econometric results}

\subsection{Principal Component Analysis}

In principal component analysis, the most commonly used criteria for solving the number-of-components problems is a rule-ofthumb, the rule known either as the Kaiser or eigenvalue-one criterion. With this approach, we can retain and interpret any component with an eigenvalue greater than or equal to 1 . However, the most important criterion for solving the "number-of-components" problem is the interpretability criterion: interpreting the substantive meaning of the retained components and verifying that this interpretation makes sense in terms of what is known about the constructs under investigation (Hatcher, 1998). Hence, following these criterions and according to the Table 1 and 2, we retain and interpret two components.

Table 1: Total Variance Explained

\begin{tabular}{|c|c|c|c|}
\hline Components & Eigenvalues & \% of Variance & Cumulative \% \\
\hline 1 & 3.229 & 32.290 & 32.290 \\
\hline 2 & 2.691 & 26.908 & 59.198 \\
\hline 3 & 1.818 & 18.181 & 77.379 \\
\hline 4 & 1.008 & 10.076 & 87.455 \\
\hline 5 & 0.442 & 4.415 & 91.870 \\
\hline 6 & 0.388 & 3.876 & 95.746 \\
\hline 7 & 0.272 & 2.719 & 98.466 \\
\hline 8 & 0.069 & 0.699 & 99.165 \\
\hline 9 & 0.058 & 0.579 & 99.744 \\
\hline 10 & 0.025 & 0.256 & 100.00 \\
\hline
\end{tabular}

Note: Extraction Method - Principal Component Analysis.

The first four components displayed eigenvalues greater than 1 . However, after interpreting the rotated solutions to 2,3 and 4 
components, the first two components were retained accounted $59,2 \%$ of the total variance. According Table 2 , we can see the rotated component matrix:

Table 2: Rotated Component Matrix

\begin{tabular}{|c|c|c|}
\hline Variables & $1^{\text {si }}$ Componenf & $2^{\text {nd }}$ Component \\
\hline$E$ & 0.135 & -0.542 \\
\hline CA/GDP & 0.138 & -0.481 \\
\hline$J / J d$ & 0.360 & -0.098 \\
\hline NPL/TBA & 0.268 & 0.768 \\
\hline M2/R & 0.058 & 0.893 \\
\hline STFD/R & -0.265 & 0.864 \\
\hline Y & 0.577 & -0.135 \\
\hline$L^{*} / G D P$ & 0.837 & -0.176 \\
\hline C/GDP & 0.951 & 0.131 \\
\hline L/GDP & 0.962 & 0.090 \\
\hline
\end{tabular}

Note: Extraction Method - Principal Component Analysis.

Rotation Method: Varimax.

In interpreting the rotated component matrix, an variable is said to load on a given component if the factor loading is 0.60 or grater for that component, and is less than 0.60 for the other (Santos and Bacha, 2002). Comrey and Lee (1992) suggest that loadings in excess of 0.63 are considered very good. The factors loading above 0.60 are highlight in Table 2. Using these criteria, we can see in Table 2 that three variables ( $\mathrm{L}^{*} / \mathrm{GDP}, \mathrm{C} / \mathrm{GDP}$ and L/GDP) are founded to load on the first component, witch can be label the financial boom component. Others three variables (NPL/TBA, M2/R and STFD/R) load on the second component, which can be label the banking and external sector problem component.

We can interpret the first two components and verify that this interpretation makes sense in terms of the degree of vulnerability of a group of 18 countries to the twin crises, currency and financial crises, in the Asian crisis context.

i) Financial Boom Component:

The ratio L/GDP is used as a proxy for the existence of deposit runs and loss of confidence in the banking system, or of the shrinkage of bank balance sheets for other reasons. The growth of the ratio $\mathrm{Cl}$ GDP is used as a proxy for how extended the banking sector is. A 
significant increase in this ratio might suggest growing strains in the bank sector. The changes in the ratio $L^{*} / G D P$ are used as a measure of the extent to which the bank system relies on foreign capital to fund its operations, and thus is a proxy for its vulnerability to a sudden withdrawal of capital inflows. The mean value of these variables increases during the pre-crisis year and then sharply declines during the crisis year (Hardy and Pazarbasioglu, 1998).

The rise in the ratios C/GDP, L/GDP and L*/GDP prior to a banking crisis is entirely accounted for in its evolution before the twin crises in agreement with Kaminsky and Reinhart (1999).

The growth of the bank assets (domestic credit) and bank liabilities (bank deposits) indicates an expansion of the banking sector. In the context of financial liberalization in the 90's, high liquidity in the international financial system and current stability in the emerging market would explain an expansion of the financial sector. Pill and Pradhan (1995) affirm that the variable that best captures the extension from which the financial liberalization has been progressing is domestic credit/GDP.

We can observe that the 1st Component is positive and strongly correlated with the financial indicators (C/GDP, L/GDP and $\mathrm{L}^{*} / \mathrm{GDP}$ ) Then, it can be interpreted as a construct of Financial Boom Component.

ii) Banking and External Sector Problems Component:

$M 2 / R$ captures the extent to which the liabilities of the banking system are backed by international reserves. In the event of a currency crisis, agents may rush to convert their domestic currency deposits into foreign currency, so that $\mathrm{M} 2 / \mathrm{R}$ captures the ability of the central bank to meet those demands. Then, the ratio of $M 2 / R$ is an indicator of the external sector as well as of the financial sector (Calvo and Mendoza, 1996).

A liquidity crisis can result from a voluminous and rapid evasion of the short-term foreign capital. Large entries of short-term capital may be attracted by the promise of high yield, market liberalization and apparent dollar-pegged currency stability. Hence, with growing signs of financial system fragility, the necessary conditions for a high ratio between short-term foreign debt and international reserves could be created, which could make a country more vulnerable to herd behavior with a quick evasion of capital. The high rates of shortterm foreign debt have signaled high vulnerability in relation to sudden changes of short-term flow of capital according to Diehl and Schweickert (1998). 
Deregulation and precariousness in the supervision of the banking sector ally as an implicit warranty by the government for the bank loans (moral hazard), their resulting in high-risk loans and in high participation of the non-performing loans in the total bank assets.

According to Krugman (1998a), the problem of moral hazard began with the financial institutions or financial intermediaries, whose responsibilities were perceived as an implicit warranty by the government, those responsibilities not being essentially regulated and, as a result, being subject to severe problems of moral hazard.

We can note that the $2^{\text {st }}$ Component is positive and strongly correlated with indicators of banking problems (M2/R and NPL/TBA) and indicators of external problems (M2/R and STFD/R). Then, it can be interpreted as a construct of Banking and External Sector Problems Component.

Kaminsky and Reinhart (1999) defend that the Asian currency crisis was the fuse of the financial crisis and of the balance-ofpayments crisis, twin crises mutually reinforced. The currency crisis generated recession and credit restriction that reinforced the financial crisis, activating a vicious spiral and expanding the process amid the emerging countries.

\subsection{Crisis scores}

Table 3 presents the estimated communalities for the twin crises indicators and their respective weights (relative communalities):

Table 3: Relative communality - leading indicators of a sample of 18 países: 1996

\begin{tabular}{|c|c|}
\hline (i) Indicators relative communality & communality \\
\hline $\begin{array}{l}1 \text { - Non-performing loans/total bank assets (NPL/TBA) } \\
0.093\end{array}$ & 0.417 \\
\hline $\begin{array}{c}2-\text { Broad money/international reserves }(\mathrm{M} 2 / \mathrm{R}) \\
0.177\end{array}$ & 0.789 \\
\hline $\begin{array}{c}3 \text { Short-term foreign debt/ infernational reserves (STFD/R) } \\
0.170\end{array}$ & 0.758 \\
\hline $\begin{array}{c}4 \cdot \text { - Bank gross foreign liabilities/GDP (L*/GDP) } \\
0.157\end{array}$ & 0.703 \\
\hline $\begin{array}{c}5 \text { - Credit to private sector/GDP (C/GDP) } \\
0.196\end{array}$ & 0.873 \\
\hline $\begin{array}{c}\text { 6. Bank deposits liabilities/GDP (L/GDP) } \\
0.206\end{array}$ & 0.920 \\
\hline $\begin{array}{c}\text { Total } \\
1.000\end{array}$ & 4.46 \\
\hline
\end{tabular}


It is important emphasize that, in Table 2, the factor loading greater than 0.60 are positives. Therefore, we use positives signs to the variables (NPL/TBA, M2/R, STFD/R, L*GDP, C/GDP and L/GDP) in the crises index that measure the degree of vulnerability of a group of 18 countries to the twin crises in the Asian crisis context .

Once the weight for every variable is established, a score can be determined to measure crisis vulnerability. The Asian crisis vulnerability score presented below is determined by the total-sum of the products of the variables standardized values presented in Table 4 by their respective weights (relative communality) in Table 3 , with the pertinent signals from principal component analysis. The larger the scores, the larger the vulnerability regarding the twin crises, according to what follows:

$$
\begin{aligned}
& \text { Score }=\phi_{1}{ }^{*}(\mathrm{NPL} / \mathrm{TBA})+\phi_{2}{ }^{*}(\mathrm{M} 2 / \mathrm{R})+\phi_{3}{ }^{*}(\mathrm{STFD} / \mathrm{R})+ \\
& \phi_{4}{ }^{*}\left(\mathrm{~L}{ }^{*} / \mathrm{GDP}\right)+\phi_{5}{ }^{*}(\mathrm{C} / \mathrm{GDP})+\phi_{6}{ }^{*}(\mathrm{~L} / \mathrm{GDP}),
\end{aligned}
$$

where $\phi_{i}(i=1,2, \ldots, 6)$ are the relative communalities of the variables presented in Table 3 and the values of the standardized variables, (NPL/TBA), (M2/R), (STFD/R), (L*/GDP), (C/GDP) and ( $L$ GDP) are presented in Table 4. Likewise, each country's score is determined by an average of the standardized variables weighted up by relative communalities (weights).

It is admitted that the larger the vulnerability of the countries to the crises, the larger the score. Moreover, the sign of each indicator to contribute for increasing the score and the vulnerability of the economies to the crises should be used. Hence, the hypothesis of the twin crises should be confirmed by making use of the external and banking sectors.

By substituting the standardized values of the indicators presented in Table 4 for each country in the formula for determining the scores, it is possible to calculate the vulnerability scores for the Asian crisis of the 18 economies in the sample, in 1996.

Although the countries with positive scores are characterized as the most susceptible to the twin crises, it is necessary to make use of a statistical method to classify the most vulnerable countries to the crises in the banking sector and in the balance-of-payments. 
Table 4: Standardized values of the leading indicators in 1996 - Nonperforming loans/total bank assets (NPL/TBA), Broad money/ international reserves $(\mathrm{M} 2 / \mathrm{R})$, short-term foreign debt /international reserves (STFD/R), bank gross foreign liabilities /GDP $\left(\mathrm{L}^{*} / \mathrm{GDP}\right)$, credit to private sector/GDP (C/GDP), bank deposits liabilities/GDP(L/GDP):

\begin{tabular}{ccccccc}
\hline Countries & NPL/TBA & M2/R & STFD/R & L*/GDP & C/GDP & L/GDP \\
Argentina & 0.45787 & -0.00367 & 0.29737 & -0.42445 & -0.83779 & -1.04765 \\
Brazil & -0.39717 & 0.16764 & $-0,35663$ & -0.48636 & -0.62474 & -0.79814 \\
Chile & -1.53723 & -0.94392 & -0.5769 & -0.56066 & 0.39393 & -0.12840 \\
Singapore & -0.82469 & -1.55920 & -1.28208 & 2.88170 & 1,73884 & 1.54813 \\
Colombia & -0.68219 & -0.91449 & -0.35028 & -0.59780 & -0.81116 & -1.10456 \\
Korea & 0.22036 & 2.02329 & 1.90222 & -0.20775 & 0.55705 & -0.02335 \\
Philippians & 1.55042 & 0.70642 & 0.00212 & 0.29374 & 0.13094 & 0.25681 \\
Indonesia & 1.28916 & 2.01348 & 1,47998 & -0.43683 & 0.34399 & 0.24367 \\
Jordan & -0.34967 & 0.25330 & -0.47886 & 2.07683 & 0.84667 & 1.62693 \\
Malaysia & 0.57662 & 0.01987 & -0.67253 & -0.07774 & 1.48916 & 1.56127 \\
Mexica & 1.19415 & 0.73257 & 2.21653 & -0.67829 & -0.97428 & -0.81565 \\
Peru & -0.56343 & -0.71834 & -0.21536 & -0.59161 & -0.86443 & -0.95135 \\
Poland & -0.34967 & -0.38225 & -1.31701 & -0.64733 & -0.97095 & -0.49173 \\
Czech R. & 1.07540 & 0.01856 & -0.55823 & 0.21326 & 0.41057 & 0.94843 \\
Sri Lanka & -0.58718 & -0.70591 & -0.43600 & -0.45540 & -0.66469 & -0.65369 \\
Thailand & 1.38416 & 0.31345 & 0.25927 & 0.86334 & 1.82872 & 1.32926 \\
Turkey & -1.58473 & 0.43442 & 0.72438 & -0.40587 & -0.75790 & -0.30788 \\
Venezuela & -0.87219 & $-1,45523$ & -0.63919 & -0.75878 & -1.23394 & -1.19211 \\
\hline
\end{tabular}

Table 5 - Scores: 1996

\begin{tabular}{cccccc}
\hline Venezuela & -1.053910 & Brazil & -0.431116 & Singapore & 0.541526 \\
Colombia & -0.765237 & Argentina & -0.392798 & Malaysia & 0.544104 \\
Poland & -0.717303 & Turkey & -0.223036 & Jordan & 0.758066 \\
Peru & -0.674446 & Mexico & 0.152057 & Korea & 0.773748 \\
Sri Lanka & -0.590111 & Czech $R$ & 0.317729 & Indonesia & 0.776910 \\
Chile & -0.445167 & Philippines & 0.394270 & Thailand & 0.996084 \\
\hline
\end{tabular}

\subsection{Cluster analysis}

The cluster analysis based on the Ward method concludes for the existence of two homogenous groups of scores.

Group 1: Argentina, Brazil, Chile, Colombia, Peru, Poland, Sri Lanka, Turkey and Venezuela. 
Group 2: Mexico, Singapore, Korea, the Philippines, Indonesia, Jordan, Malaysia, the Czech Republic and Thailand.

The five countries in Group 2 that presented larger scores stand out as indicators of greater vulnerability to the twin crises; in decreasing order, they were Thailand, Indonesia, Korea, Jordan, and Malaysia. Note that meanwhile Jordan present a high score - great vulnerability - this country was not reached strongly by the crisis. We can note also that the crisis in the Philippines, a country with better fundaments and a less fragile financial system than other countries in the region, was also relatively contained. Even though the exchange rate plunged and the stock market dropped by over $30 \%$ in 1997, this country did not experience the extent of the turmoil and financial panic that hit Korea, Thailand, Indonesia and Malaysia. Likewise, Singapore was, relatively speaking, less affected by the regional turmoil. Singapore decided to let their currency float rather than lose reserves by attempting to stabilize the exchange rate; however, the depreciation rates of their currency was modest, and, most importantly, the country did not experience drastic reversals in market sentiment, financial panic and large-scale debt crises (Corsetti, Pesenti and Roubini, 1998). The scores of Mexico and the Czech Republic also show that these countries were less vulnerable to the regional turmoil.

It is also interesting to observe that the Latin American countries belong to cluster of countries less vulnerable to the twin crises in 1996. Contrary to the foreign investors' optimistic perception in relation to East Asia countries, the Latin American economies were seen with distrust by part of the investors, even though they have also been benefited by the capital inflow, but in smaller proportion than East Asia countries. That perception of greater risk regarding those economies certainly reduced the financial leverage and this minimized the problems of moral hazard presented by East Asia countries.

\subsection{Discriminant analysis}

The validation of the stratification in two groups is taken to effect by using the discriminant analysis, according to Table 6 . This procedure hasn't indicated a mismatch even when the data were submitted to the cross validating option (Everitt and Der, 1996). 
We also use nonparametric discriminant analysis. The nonparametric method is describe in Conover (1999), that propose to classify the observations by application of the rank transformation. Each variable is ranked separately, and the popular linear discriminant function is computed on the ranks. Hence, we can verify if the countries were correctly classified by discriminant analysis, independent of their distributions hypothesis. The usual parametric discriminant analysis assumes a normal distribution for multivariate data, although this distribution is not common. The nonparametric approach is compared with the parametric one. Mismatching in the results does not suggest normality of the populations. Our results are coincident for both procedures.

Table 6: Classification of the countries (1996) according to the linear discriminant function

\begin{tabular}{ccccc}
\hline & & Classified & Posteriori Probability of Countries in \\
Countries & From & Group & Group \\
into Group & 1 & 2 \\
\hline Argentina & 1 & 1 & 0.999 & 0.001 \\
Brazil & 1 & 1 & 0.999 & 0.001 \\
Chile & 1 & 1 & 1.000 & 0.000 \\
Singapore & 2 & 2 & 0.000 & 1.000 \\
Colombia & 1 & 1 & 1.000 & 0.000 \\
Korea & 2 & 2 & 0.000 & 1.000 \\
Philippines & 2 & 2 & 0.001 & 0.999 \\
Indonesia & 2 & 2 & 0.000 & 1.000 \\
Jordan & 2 & 2 & 0.000 & 1.000 \\
Malaysia & 2 & 2 & 0.000 & 1.000 \\
Mexico & 2 & 2 & 0.064 & 0.936 \\
Peru & 1 & 1 & 1.000 & 0.000 \\
Poland & 1 & 1 & 1.000 & 0.000 \\
Czech R. & 2 & 2 & 0.003 & 0.997 \\
Sri Lanka & 1 & 1 & 1.000 & 0.000 \\
Thailand & 2 & 2 & 0.000 & 1.000 \\
Turkey & 1 & 1 & 0.979 & 0.021 \\
Venezuela & 1 & 1.000 & 0.000 \\
\hline
\end{tabular}




\section{Concluding comments}

The results of the Principal Component Analysis show that three variables (L*/GDP, C/GDP and L/GDP) are founded to load on the first component, witch can be label the financial boom component. Others three variables (NPL/TBA, M2/R and STFD/R) load on the second component, which can be label the banking and external sector problem component.

The index with base in six variables regarding both components reveal themselves to be reasonable indictors of vulnerability the of the Twin Crises. The results of the cluster analysis classify the main protagonists of the East Asia crisis (Thailand, Indonesia, Korea and Malaysia) in the group of the most vulnerable economies of the twin crises, but they also classify countries that are not reached strongly by the crisis, such as: Mexico, Singapore, Jordan, The Philippines and the Czech Republic. We can also observe that the Latin American countries belong to cluster of countries less vulnerable to the twin crises in 1996. The perception of greater risk regarding those economies can have reduced the financial leverage and this minimized the problems of moral hazard presented by East Asia countries. Asian countries' financial systems are inherently more bank-dominated systems, and thus due to structural economic differences more sensitive to twin crises. We stand out that our approach methodological doesn't function as an early warning system, but just as an vulnerability indicator of the twin crises. In this way, it was confirmed that the East Asia crisis resulted from financial crisis and balance-of-payments unbalance, twin crises. That result corroborates the position in the specialized literature, especially that of Kaminsky and Reinhart's (1999).

\section{Data Appendix}

Sources of the indicators: Almost all the data presented were gathered from the International Monetary Fund (IMF), in International Financial Statistics (various issues), except when stated otherwise.

1. The real exchange rate was calculated according to what follows (Mattos, 1987):

Consumer Prices ...line $64($ USA-1996) $=102,9$

Consumer Prices ...line $64($ USA-1994 $)=97,3$ 
$(102,9) /(97,3)=1.057$

(line 64 of the country in 1996)/(line 64 of the country in 1994) $=\mathrm{Z}$

[(line $\mathrm{rf}$ of the country in 1994).(Z)/(1.057)] $=\mathrm{X}$

$\{[(\mathrm{X}) / \text { (line } \mathrm{rf} \text { of the country in 1996) }]-1\}^{*} 100>0$ (Appreciation)

$\{[(X) / \text { (line rf of the country in 1996) }]-1\}^{*} 100<0$ (Depreciation).

2. Current account balance relative to GDP: [line 78ald $\mathrm{x}$ line rf )/ line $99 \mathrm{~b}]^{*} 100$.

3. M2/Reserves: $\left\{[\text { (line } 34+\text { line 35) / (line rf) ] / (line 1L.d) }\}^{*} 100\right.$.

4. Short-term foreign debt relative to gross international reserves: World Development Indicators - 1998. [(Total external debt - Longterm debt ) / (line lLd) ] ${ }^{*} 100$.

5. Bank gross foreign liabilities relative to GDP: [ (line 26c / line 99b) $]^{*} 100$.

6. Credit to private sector relative to GDP: [(line $22 \mathrm{~d} /$ line $99 b)]^{*} 100$.

7. Bank deposits liabilities relative to GDP: [(line $24+$ line 25$) /($ line $99 \mathrm{~b})]^{*} 100$.

8. Ratio of lending-to-deposits interest rate: [(line $60 \mathrm{p} /$ line $601)]^{*} 100$.

9. Non-Performing Loans relative to total bank assets: BIS Annual Report (various issues). (NPL/TBA)* 100.

10. Real GDP growth: \{[(ine 99b.p in 1996)/(line 99b.p in 1994)]$1\}^{*} 100$.

\section{References}

Bank for International Settlements. (1997). Annual Report.

Arbex, Marcelo A. e Fontes, Rosa. (1999) "Credibilidade das políticas econômicas no Brasil: uma análise empírica do período 1991-1998". Economia Aplicada, V.3, n.1.

Calvo, Guillermo A. (1995). Varieties of Capital-Market Crises. Mimeo, University of Maryland.

Calvo, Guillermo A. ; Enrique G. Mendoza. (1996). "Mexico's balance-of-payments crisis: a chronicle of a death foretold". Journal of International Economics, V. 4I: 235-264.

Comrey, A L., and Lee, H. B. (1992). A First Course in Factor Analysis. (2nd ed.). Hillsdale, NJ: Lawrence Erlbaum Associates, Publishers.

Conover, W.J. (1999). Practical Nonparametric Statistics. Third Edition, John Wiley $\mathcal{E}$ Sons, Inc. 
Corsetti, G., Pesenti, P. ; N. Roubini. (1998). Fundamental determinants of the Asian crisis: a preliminary empirical assessment. www.stern.nyu.edu./ nroubini/asia/ Asian.

Díaz-Alejandro, Carlos F. (1985). " Good-Bye Financial Repression, Hello Financial Crash." Journal of Development Economics, February, 19 (1-2), pp.1-24.

Diehl, M. ; R. Schweickert. (1998). "Currency crisis: Is Asia different?" Institute of World Economics, Kiel Discussion, n.309, Kiel, (January).

Eichengreen, Barry. (2000). A Globalização do Capital. São Paulo: Editora 34. Trad. Por Sergio Blum de Globalizing Capital (New Heaven: Princeton University Press).

Everitt, B.S. ; G. Der. (1996). A Handbook of Statistical Analyses Using SAS. Nova York - Chapman 8 Hall.

Everitt, B.S. ; Dunn, G. (2001). Applied Multivariate Data Analysis. London: 2nd Ed., Arnold.

Galbis, V. 1993. "High Real Interest Rates under Financial Liberalization: Is There a Problem?" IMF Working Paper. Washington: International Monetary Fund, n.7, (January).

Giambiagi, Fábio e Moreira, Maurício Mesquita. (1999). "Taxa de juros e de câmbio real após a desvalorização do Real: um cenário tentativo para 1999/2002". Revista do BNDES, Junho.

Glick, R. ; M. Hutchison. (1999). Banking and currency crises: how common are twins? http://ideas.uqam.ca/iedas/data/Papers/fipfedfpb99-07.html.

Goldfajn, Ilan and Valdés, Rodrigo O. (1995). Balance-of-Payments Crises and Capital Flows: The Role of Liquidity. Mimeo, Massachusetts Institute of Technology.

Hardy, Daniel C. ; Pazarbasioglu, C. (1998). "Leading Indicators of Banking Crises: Was Asia Different?" . IMF Working Paper, Washington: International Monetary Fund, n.91 (July).

Harman, Harry H. (1976). Modern Factor Analysis. Chicago: Third Edition, The University of Chicago Press.

Hatcher, L. (1998). A Step-by-Step Approach to Using the SAS System for Factor Analysis and Structural Equation Modeling. SAS Institute Inc.

Hermann, Jennifer. (1999). "Ancoragem cambial em ambiente de elevada mobilidade internacional do capital: alcance, limites e soluções". Estudos econômicos, USP, São Paulo, n.29(v.4), p.475-511, out/dez.

Hoffmann, R.A (1999). "Componentes Principais e Análise fatorial". Piracicaba: ESALQ/USP, 1999. Série Didática, n.90.

International Monetary Fund. (1999). International Financial Statistics, (annual). 
Kaminsky, G. ; Carmen M. Reinhart. (1996). "The Twin Crises: The Causes of Banking and Balance-of-Payments Problems". International Finance Discussion Paper, n.544 (march). Washington: Board of Governors of the Federal Reserve System.

Kaminsky, G.; Carmen M. Reinhart. (1998). "Leading Indicators of Currency Crises". IMF Staff Papers 45, pp. 1-48.

Kaminsky, G.; Carmen M. Reinhart. (1999). "The Twin Crises: The Causes of Banking and Balance-of-Payments Problems". The American Economic Review, V.89, n.3 (June): 473-500.

Krugman, P. (1998a). What happened to Asia? www.mit.edu/people/krugman.

Krugman, P. (1998b). Jaoan's Bank Bailout: Some Simple Arithmetic. web.mit.edu/ krugman.

Manly, Bryan F.J. 1986 [1994]. Multivariate Statistical Methods - A Primer. London: 2a.ed., Chapman $\mathcal{Z}$ Hall.

Menezes, Adriano C. e Moreira, Tito Belchior S. (2001). "O modelo de Krugman explica a crise cambial brasileira em janeiro de 1999?" Análise Econômica, ano 19, n.36, setembro.

Miller, Victoria. (1995). Central Bank Reactions to Banking Crises in Fixed Exchange Rate Regimes. Mimeo, Université de Québec à Montréal.

Miranda, Mauro Costa. (1999). Crises cambiais e ataques especulativos no Brasil: janeiro de 1982 a janeiro de 1999. Tese de Mestrado pela UNB, Julho.

Mishkin, Frederic S. (1996). "Understanding Financial Crises: A Developing Country Perspective", NBER Working Paper, Cambridge, Massachusetts- National Bureau of Economic Research, n.5600 (June).

Mollo, Maria de Lourdes Rollemberg e Silva, Maria Luiza Falcão. (1999). "A liberalização do câmbio no Brasil: revisitando a discussão dos pressupostos teóricos embutidos nas prescrições cambiais alternativas". Estudos Econômicos, USP, São Paulo, n.29 (2), p.189-227, abr.jun.

Moreira, Tito Belchior S. (2002). "Fatores Determinantes de Crises Cambiais e Bancárias". Revista Econômica do Nordeste, Fortaleza, V.33, n.2, abr-jun.

Pill, H. ; Pradhan, M. (1995). "Financial Indicators and Financial Change in Africa e Asia". IMF Working Paper. Washington: International Monetary Fund, n.123 (November).

Puga, F.P. (1999). "Sistema Financiero Brasileiro: reestruturação recente, comparações internacionais e vulnerabilidade à crise cambial". In: Giambiagi, F. e Moreira, M. (1999). A Economia Brasileira nos anos 90. Rio de Janeiro, BNDES.

Sanchez, I. (1999). A internacionalização da economia. São Paulo, Editora Senac.

Santos, Alesandra B. dos and Bacha, Carlos José C. (2002). "Evoluçāo Diferenciada da Lavoura de Soja e de seu Processamento Industrial no Brasil - Período de 1970 a 1999". Economia Aplicada - Brazilian Journal of Applied Economics. Vol.6, n.1, Jan-Mar. 
Schwartsman, Alexandre. (1999). "A crise cambial e o ajuste fiscal". Revista de Economia Política, (19) , n.1, p.73, jan-mar.

Soros, G. (1999). "A crise do Capitalismo - As ameaças aos valores democráticos - As soluçōes para o capitalismo global." Rio de Janeiro: Editora Campos, 3a Ed. , Trad. Por Afonso Celso da Cunha Serra de The Crisis of Global Capitalism, Ed. Public Affairs - 1999 (local n.d.)

Tabachnick, Barbara G. ; Fidell, Linda S. (2001). Using Multivariate Statistics. Boston: Fourth Edition, Allyn and Bacon.

Velasco, A. (1987). "Financial Crises and Balance of Payments Crises: A Simple Model of the Southern Cone Experience". Journal of Development Economics, V.27 (October): 263-83.

Wichern, Dean W. ; Richard A. Johnson. (1998). Applied Multivariate Statistical Analysis. 4a . ed, Englewood (N.J.): Prentice-Hall, Inc.

Wise, Carol (2001). "Currency Board da Argentina: os Laços que Unem?" Revista de Economia Politica, Vol. 21, n. $^{\circ} 3$ (83), jul-set.

World Bank. 1998, (2000). World Development Indicators.

World Bank. (1998) , (1999). World Economic Outlook. 